\title{
Characteristic Behavior of Bucket Foundations
}





\section{Characteristic Behavior of Bucket Foundations}

PhD Thesis by

Amin Barari

Department of Civil Engineering, The Faculty of Engineering and Science, Aalborg University, Aalborg, Denmark

River Publishess

Aalborg 
ISBN 978-87-92982-25-4 (e-book)

Published, sold and distributed by:

River Publishers

P.O. Box 1657

Algade 42

9000 Aalborg

Denmark

Tel.: +45369953197

www.riverpublishers.com

Copyright for this work belongs to the author, River Publishers have the sole right to distribute this work commercially.

All rights reserved (c) 2012 Amin Barari.

No part of this work may be reproduced, stored in a retrieval system, or transmitted in any form or by any means, electronic, mechanical, photocopying, microfilming, recording or otherwise, without prior written permission from the Publisher. 
Project duration

$1^{\text {st }}$ December 2008-1 $1^{\text {st }}$ December 2011

Supervisor

Principal supervisor

Professor Lars Bo Ibsen

Department of Civil Engineering

Aalborg University

Aalborg, Denmark

\section{Assessment Committee members}

Professor Martin Achmus

Institute of Soil Mechanics

Leibniz University of Hannover

Hannover, Germany

Professor Guido Gottardi

Department of Civil, Environmental and Materials

Università di Bologna

Bologna, Italy

Professor Lars Damkilde

Department of Civil Engineering

Aalborg University

Aalborg, Denmark 



\section{TABLE OF CONTENTS}

Table of contents.......................................................................

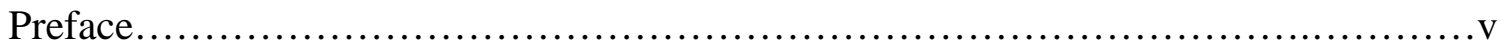

Organisation of the Ph.D. thesis..........................................................

List of scientific papers..........................................................

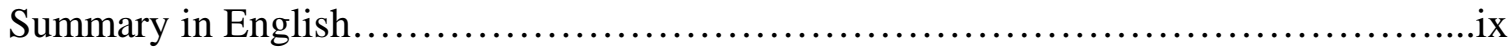

Summary in Danish............................................................. xii

1. General introduction............................................................

1.1 Bucket foundations.......................................................

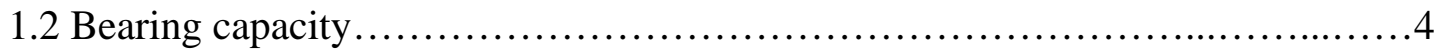

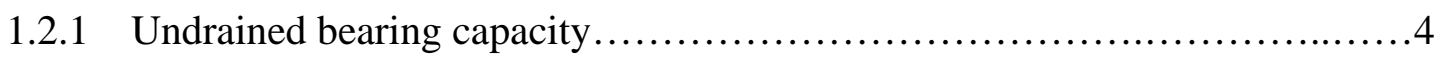

1.2.2 Drained bearing capacity.................................................

1.3 Water penetration in unsaturated soils............................................

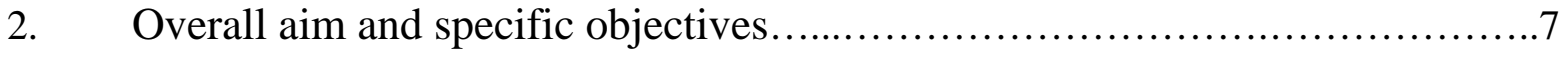

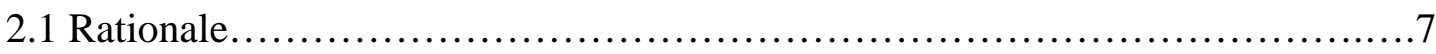

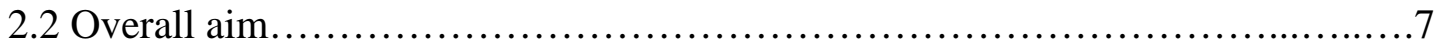

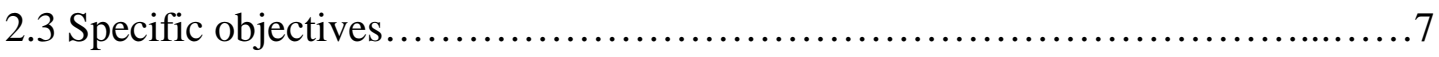

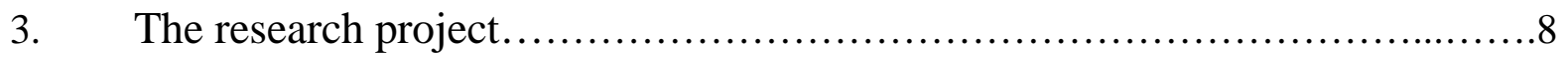

3.1 Characteristic behavior of Bucket foundations...................................

3.2 Modeling of water flow through porous media.................................14

4. Conclusions and recommendations for future research.........................17

4.1. Characteristic behavior of Bucket foundations.............................18

4.1.1 Monotonic loading of circular surface footings on clay.....................18

4.1.2 Vertical capacity of Bucket foundations in undrained soil...................19

4.1.3 Undrained response of Bucket foundations to moment loading................21

4.1.4 Modeling of water flow through porous media............................23

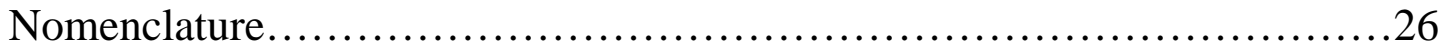


Literature cited.

Scientific papers

35

\section{Paper I}

Ibsen, L.B. \& Barari, A. (2011). Monotonic loading of circular surface footings on clay. Journal of Mechanical Science and Technology 25, No. 12, 3151-3158.........36

\section{Paper II}

Barari, A. \& Ibsen, L.B. Vertical capacity of Bucket foundations in undrained soil. Journal of Civil Engineering and Management, in press.

\section{Paper III}

Barari, A. \& Ibsen, L.B. (2012). Undrained response of Bucket foundations to moment loading. Applied Ocean Research 36, 12-21.

\section{Paper IV}

Ghotbi, Abdoul R. Ghotbi., Omidvar, M. \& Barari, A.(2011). Infiltration in unsaturated soils - An analytical approach. Computers and Geotechnics 38, No.6, 777-782. 101 


\section{Preface}

The present thesis "Characteristic behaviour of bucket foundations" has been prepared in connection with a Ph.D. study carried out at the Department of Civil Engineering, Aalborg University, Denmark within the period December 2008 to December 2011. The thesis is presented as a collection of peer-reviewed articles published and submitted during this period in a number of journals.

I wish to express my appreciation to my supervisor Professor Lars Bo Ibsen, Department of Civil Engineering, Aalborg University. I would like to thank his guidance and support during my study. Professor Ibsen has extensive experience in the field of offshore geotechnics due to his involvement in the development of offshore bucket foundations for wind turbines. The friendly environment of his research group can not be forgotten.

The Universal Foundation A/S is acknowledged for its support. Without this economic support, anything of this work would not be possible to carry out.

Finally, i would like to thank my parents for their patience, encouragement and everlasting support during this time. 


\section{ORGANISATION OF THE PH.D THESIS}

This Ph.D. thesis includes four scientific papers, originating from the Ph.D. research project; three are published in scientific journals, and one is accepted for publication. The introductory chapters of this thesis include background information of the offshore bucket foundations and the bearing capacity concepts for skirted foundations. Unsaturated flow in unsaturated soils introduced by Richard, the overall aim and specific objective of the current research project as well as a presentation of the selected articles are also described in this chapter.

Moreover, the conclusions and recommendations for future research based on the topics presented and discussed within the four journal papers are presented. A list of the articles

related to the research project available in the literature as well as the references in each journal paper are given. 


\section{LIST OF SCIENTIFIC PAPERS}

\section{Paper 1}

Ibsen, L.B., Barari, A. 2011. Monotonic loading of circular surface footings on clay, Journal of Mechanical Science and Technology, 25(12), 3151-3158.

\section{Paper 2}

Barari, A., Ibsen, L.B. 2012. Vertical capacity of bucket foundations in undrained soil, Journal of Civil Engineering and Management, in press.

\section{Paper 3}

Barari, A., Ibsen, L.B.2012. Undrained response of Bucket foundations to moment loading, Applied Ocean Research, 36, 12-21.

\section{Paper 4}

Ghotbi, Abdoul R., Omidvar, M., Barari, A. 2011, Infiltration in unsaturated soils- An analytical approach, Computers and Geotechnics, 38(6), 777-782. 


\section{SUMMARY IN ENGLISH}

The world is currently facing serious problems brought about by oil dependence. Reducing oil consumption provides an opportunity to increase competitiveness, technological development, and progress. Wind energy is currently the most costcompetitive form of renewable energy, and there are strong political and industrial forces (particularly in northern Europe) supporting the development of the offshore wind industry.

Offshore structures may consist of a single shallow foundation such as gravitybased platforms or multiple shallow foundations acting in concert (e.g., jack-up rigs or tension leg platforms). General loading is particularly relevant in the design of shallow foundations for offshore structures because wind, wave, and current forces produce substantial lateral load components at magnitudes that are not commonly encountered onshore.

Bucket foundations were pioneered in the offshore oil and gas industry and have recently been used in offshore wind turbines. The bucket foundation is a welded steel structure consisting of a tubular center column connected to a steel bucket through flange-reinforced stiffeners.

The overall aim of the research presented in this thesis was to improve the design of offshore wind turbine foundations. The work was divided into two main research efforts: geotechnical engineering experiments to gain insight into the behavior of offshore bucket foundations, and development of methods to improve the study of infiltration into unsaturated soils, an important problem in geo-environmental engineering. The outcomes of the research have the potential to directly or indirectly reduce the risks and costs related to offshore geotechnics.

1. Characteristic Behavior of Bucket Foundations: Design guidance for calculating the bearing capacity of offshore shallow foundations is provided in ISO (2000), DNV (1992), and API (2000) standards, among others. Despite the clear differences between offshore and onshore shallow foundation systems and loading conditions, the roots of the design methods presented in the recommended practices are the same 
as those employed in onshore design. These methods are ultimately based on classical bearing capacity equations for failure of a vertically loaded strip foundation on a uniform Tresca soil combined with various modification factors to account for load orientation (in terms of inclination and eccentricity), foundation shape, embedment, and soil strength profile.

A series of comprehensive experimental and numerical investigations were carried out to develop guidelines for estimating the bearing capacity of bucket foundations. The aim was to facilitate the design of low-cost and low-risk support structures to improve the economic feasibility of future offshore wind farms. These fundamental investigations were presented in three research articles including "Monotonic Loading of Circular Surface Footings on Clay," "Vertical Capacity of Bucket Foundations in Undrained Soil," and "Undrained Response of Bucket Foundations to Moment Loading.”

The initial analyses were supported by data from 6 plate load tests using diameters of 20 and $30 \mathrm{~cm}$. The failure values, deformations, and $E$ values for the circular surface footings under monotonic vertical loading were determined from these tests.

The mechanical properties of clay soils measured in laboratory tests of field samples were varied in numerical parametric analyses to investigate their effects on the bearing capacity of the circular surface footings.

In order to examine the effect of foundation geometry and to construct a methodology capable of properly addressing the increased bearing capacity due to embedment while incorporating an alternative to traditional depth factor relationships, small scale bucket foundations situated on Baltic clay were tested using embedment ratios of $0.25,0.50,0.75$, and 1 . The numerical models successfully predicted the effect of variations in soil modulus on the ultimate limit states. The results readily explained how variations in skirt length affected the bearing capacity in vertical loading experiments, resulting in an increase in pure bearing capacity for the two samples when moving from $d / D=0$ to $d / D=0.5$. In addition, the alternative expression for depth factor was capable of accurately simulating the relationship between the ultimate uniaxial vertical load and the embedment ratio. 
Finally, the complex stresses present in homogeneous soils during general loading of bucket foundations were addressed in a third article. It is more realistic to explicitly consider the interaction of these different loading components when determining the bearing capacity. Small scale bucket foundations with embedment depths ranging from 0 to 1 exposed to different load paths were selected to accurately capture the undrained response of bucket foundations. Undrained conditions are ubiquitous in offshore projects, and may persist for months or years due to the large size of offshore foundations.

Numerical models indicated that the ultimate horizontal load capacity of skirted foundations is governed by a translational scoop mechanism due to coupling of the horizontal and moment degrees of freedom, while an internal mechanism is observed within the bucket due to soil deformation.

2. Modeling of Water Flow through Porous Media: The Richards expression was initially formulated by Lorenzo Richards in 1931 to describe the movement of water in unsaturated soils. It is a partial differential equation resistant to numerical solution due to its strongly nonlinear behavior. Nevertheless, this is a fundamental equation in geotechnical engineering and is used to model the flow of water through unsaturated soils. The soil seepage flow occurring when suction is applied during foundation installation may be modeled using the Richards expression, but the existing numerical and analytical methods often have too many restrictions for practical situations.

The main contribution of this research effort was to approximate a solution to the Richards equation using a novel semi-analytical technique known as the Homotopy Analysis Method (HAM). The basic idea in applying HAM (described in detail by Liao (2004) and Ghasemi et al. (2012)) is to assume that the solution may be written as a series in terms of certain base functions in which the series satisfies the boundary conditions at infinity and is constructed in such a way that the functions converge to the exact analytical solutions provided the series contains a sufficient number of terms. 
In contrast to previous solutions that yielded a non-converging series to the problem under consideration, convergence was adequately achieved within the HAM results due to the presence of the convergence-control parameter.

The outcomes of each of the research contributions are summarized in four research articles, either directly or indirectly, and will assist in increasing the economic feasibility of future offshore projects. 


\section{SUMMARY IN DANISH (SAMMENDRAG)}

Verden er i øjeblikket står over for alvorlige problemer som følge af afhængigheden af olie. Reduktion afolieforbrug giver mulighed for at øge konkurrenceevnen, den teknologiske udvikling og fremskridt. Vindenergi er i øjeblikket den mest omkostningseffektive konkurrencedygtige form for vedvarende energi, og der er stærkepolitiske og industrielle kræfter (især i Nordeuropa) støtte til udvikling af offshore vindkraft.

Offshore strukturer kan bestå af en enkelt flad fundament såsom tyngde-baserede platforme eller flerelavvandede fonde, der handler i fællesskab (f.eks jack-up rigge eller strækforankring platforme). Generelbelastning er særligt relevant i udformningen af lavvandede fundamenter til offshore konstruktioner, fordi vind-, bølge, og nuværende kræfter producere betydelige sideværts belastning komponenter på størrelser, der ikke eralmindeligt forekommende på land. Bucket fonde blev pioner inden for offshore olie-og gasindustrien og har for nylig været anvendt i offshorevindmøller. Skovlen fundamentet er en svejset stålstruktur bestående af et rørformet midtersøjlen forbundet til et jern spand gennem flangen-forstærkede afstivninger.

Det overordnede mål for forskningen præsenteret i denne afhandling var at forbedre udformningen af offshorevindmøllefundamenter. Arbejdet blev opdelt i to hovedområder forskningsindsatsen: geotekniske tekniskeeksperimenter at få indsigt i den adfærd offshore spand fonde og udvikling af metoder til forbedring af studiet afinfiltration i umættede jord, et vigtigt problem i geo-miljøteknik. Resultaterne af forskningen har potentiale tildirekte eller indirekte reducere de risici og omkostninger i forbindelse med offshore geoteknik.

1. Karakteristisk opførsel af Bucket Foundations: Design vejledning til at beregne bæreevne offshore korte fundamenter er tilvejebragt i ISO (2000), DNV (1992), og API (2000) standarder, blandt andre. Trods de klare forskelle mellem offshore og onshore lavvandede fundament systemer og lastekonditioner er rødderne af de beregningsmetoder præsenteret i de anbefalede praksis de samme som dem, der 
anvendes i land-design. Disse metoder er i sidste ende baseret på klassiske bærende kapacitet ligninger for svigt af en lodret belastede strimmel grundlaget for en ensartet Tresca jord kombineret med forskellige modifikationer faktorer til grund for belastning orientering (i form af lyst og excentricitet), foundation form, nedstøbning, og jord styrke profil.

En række omfattende eksperimentelle og numeriske undersøgelser blev udført for at udarbejde retningslinjer til vurdering af bæreevne spand fundamenter. Formålet var at lette design af lave omkostninger og lav risiko støttestrukturer for at forbedre den økonomiske gennemførlighed af fremtidige havmølleparker.Disse grundlæggende undersøgelser blev præsenteret på tre videnskabelige artikler herunder "monoton Loading af cirkulær overflade Sokler på Clay", "Lodret kapacitet Bucket Foundations i udrænet jord," og "udrænede reaktion på Bucket Foundations til øjeblik Indlæser."

De første analyser blev understøttet af data fra 6 plade belastningsforsøg med diametre på 20 og $30 \mathrm{~cm}$.De manglende værdier, deformationer og E værdier for den cirkulære flade fundament under monoton lodret belastning blev bestemt ud fra disse tests.

De mekaniske egenskaber af lerjord målt i laboratorietest af prøveoptagning blev varieret i numeriske parametriske analyser til at undersøge deres virkninger på bæreevnen af de cirkulære overflade fundament.

For at undersøge effekten af fundamentet geometri og at konstruere en metode er i stand til korrekt at behandle den øgede bæreevne på grund af forankring, mens indarbejde et alternativ til traditionelle dybde faktor relationer, blev små spand fundament beliggende på Baltic ler testet ved hjælp af indstøbning forhold mellem $0,25,0,50,0,75$ og 1 . De numeriske modeller held forudsagde effekten af variationer i jord modul på brudgrænsetilstande. Resultaterne let forklares, hvorledes variationer i skørtet længde påvirket bæreevne i lodrette belastning eksperimenter, hvilket resulterer i en stigning i ren bæreevne for de to prøver ved bevægelse fra $\mathrm{d}$ / D = 0 til d / $\mathrm{D}=0$,5. Desuden var den alternative udtryk for dybde faktor i stand til nøjagtigt at simulere forholdet mellem den endelige énaksede lodrette belastning og indlejringen forhold. 
Endelig blev de komplekse spændinger til stede i homogene jord under generel læsning af spand fundamenter behandles i en tredje genstand. Det er mere realistisk at eksplicit at overveje samspillet mellem disse forskellige doseringsbestanddele ved fastsættelsen af bæreevne. Små bucket fundamenter med indlejring dybder 0-1 udsat for forskellige belastningsveje blev udvalgt til nøjagtigt at fange udrænede respons spand fundamenter. Udrænede betingelser er allestedsnærværende i offshore projekter, og kan vare i måneder eller år på grund af den store størrelse af offshore fundamenter.

Numeriske modeller viste, at den ultimative vandret bæreevne skirted fonde ledes af en translationel scoop mekanisme på grund af kobling af de horisontale og nu frihedsgrader, mens en intern mekanisme er observeret inden for spanden på grund af jord deformation.

\section{Modellering af vandstrømmen gennem porøse medier:}

Den Richards 'udtryk blev oprindeligt formuleret af Lorenzo Richards i 1931 at beskrive bevægelsen af vand iumættede jord. Det er en partiel differentialligning modstandsdygtig over for numerisk løsning på grund af detsstærkt ulineær adfærd. Ikke desto mindre, dette er en grundlæggende ligning i geoteknik og bruges til atmodellere strømmen af vand gennem umættede jord. Jorden nedsivning flow forekommer, når der påføres sugunder fundamentet installationen kan modelleres ved hjælp af Richards udtryk, men de eksisterende numeriskeog analytiske metoder ofte har for mange restriktioner for praktiske situationer.

Den vigtigste bidrag denne forskningsindsats var at tilnærme en løsning på Richards ligningen under anvendelse af en hidtil ukendt semi-analytisk teknik kendt som Homotopi analyse (HAM). Den grundlæggende idé at anvende HAM (beskrevet i detaljer af Liao (2004) og Ghasemi et al. (2011)), er at antage, atopløsningen kan skrives som en serie med hensyn til visse base funktioner, hvor serien opfylderrandbetingelser på uendelig og er konstrueret på en sådan måde, 
at de funktioner konvergerer de eksakteanalytiske løsninger, serien indeholder et tilstrækkeligt antal termer.

I modsætning til tidligere løsninger, viste en ikke-konvergerende serie på problemet er under overvejelse,er konvergens tilstrækkelig opnået inden for HAM resultater på grund af tilstedeværelsen af konvergens-styreparameter. I modsætning til den foregående løsninger gav en ikke konvergerende serie på

problemet under overvejelse, som tiden er gået, er konvergens tilstrækkelig grad nås inden for HAM resultater på grund af tilstedeværelsen af konvergens-kontrol parameter.

Resultaterne af hver af de forskningsmæssige bidrag er sammenfattet $\mathrm{i}$ fire videnskabelige artikler, enten direkte eller indirekte, og vil bistå med at øge den økonomiske gennemførlighed af kommende offshore-projekter. 


\section{GENERAL INTRODUCTION}

Breaking the dependence on fossil fuels offers many opportunities for strengthened competitiveness, technological development and progress. Offshore wind power is a domestic, sustainable and largely untapped energy resource that provides an alternative to fossil fuels, and is a clean energy source that can be relied on for the longterm future. Today, the modern offshore wind turbine creates reliable, cost-effective, pollution free energy for renewable energy and its behavior analysis is therefore of great importance.

Offshore wind turbines structures are traditionally founded on gravity concrete foundations or on mono-piles. In recent times, shallow foundations have become more diverse, and now include concrete or steel bucket foundations used as anchors for floating platforms or as foundation for a variety of (usually) small sea bottom structures.

The bucket foundation for offshore wind turbines is known from the offshore oil and gas industry but the load condition in this connection is however very different from offshore wind turbines. The loads from offshore wind turbines are characterized by vertical weight due to slender construction combined with horizontal forces including a large overturning moment.

\subsection{BUCKET FOUNDATIONS}

The bucket foundation is a welded steel structure consisting of a tubular center column connected to a steel bucket through flange-reinforced stiffeners (intermediate part, see Fig. 1). Stiffeners distribute loads from the tubular center column to the bucket edges. The wind turbine tower is connected to the tubular center column with a flange connection. The lower part of this flange connection is welded onto the tubular center column during production of the bucket, and no transition piece is needed. The wind turbine tower is connected to the flange above mean sea level. 


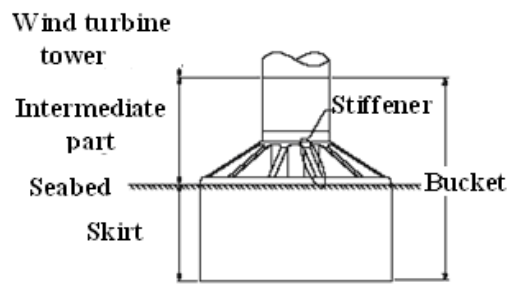

(a) Definition of the different parts

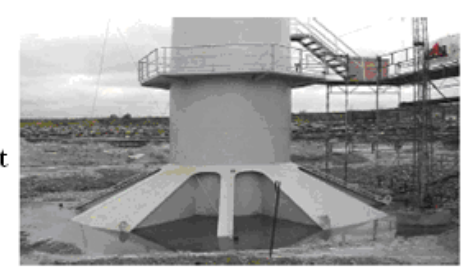

(b) The prototype in the embanked area

Fig. 1. Definitions and illustration of the prototype bucket foundation in Frederikshavn

The steel bucket consists of a vertical steel skirt extending down from a horizontal base resting on the soil surface. A prototype of the bucket foundation is shown in Fig. 1. The bucket is installed by means of suction. Lowering the pressure in the cavity between the bucket and the soil surface causes water flow to be generated, which reduces the effective stresses around the tip of the skirt and the penetration resistance. The installed bucket foundation is influenced by a large moment, due to loads from the wind on the wind turbine. The stability of the foundation is ensured by a combination of earth pressures on the skirt and the vertical bearing capacity of the bucket.

Loading regimes on offshore turbines markedly differ from structures encountered in the offshore oil and gas industry: they are generally found in much shallower water (10 m - $20 \mathrm{~m}$ ) and are relatively light (for example, 600-ton mass and 6MN vertical dead load). Moreover, in proportion to the vertical load, the horizontal loads and overturning moments are large: under extreme conditions, the horizontal load may be about $60 \%$ of the vertical load, as discussed by Houlsby et al. (2005).

The installation process can be divided into two phases: phase 1, self-penetration of the bucket; and phase 2, penetration of the bucket by applied suction. In phase 1, the skirt penetrates into the seabed as a result of its weight. In phase 2, penetration is caused by the application of suction to the inside of the bucket. The suction creates an upward flow in the soil within the bucket, which reduces the effective stresses in the soil beneath the skirt tip and causes a net downward force on the bucket lid. This reduction in effective stresses greatly reduces the penetration resistance, allowing the skirt to penetrate the soil even further. 
The first bucket foundation for a fully operational wind turbine was installed in Frederikshavn, a city in the northern part of Jutland, Denmark (Ibsen et al. 2005) which is shown in Figs. 2 and 3 prior to and upon installation, respectively. Installation of the bucket foundation was carried out by the geotechnical department of Aalborg University (Ibsen et al. 2005).

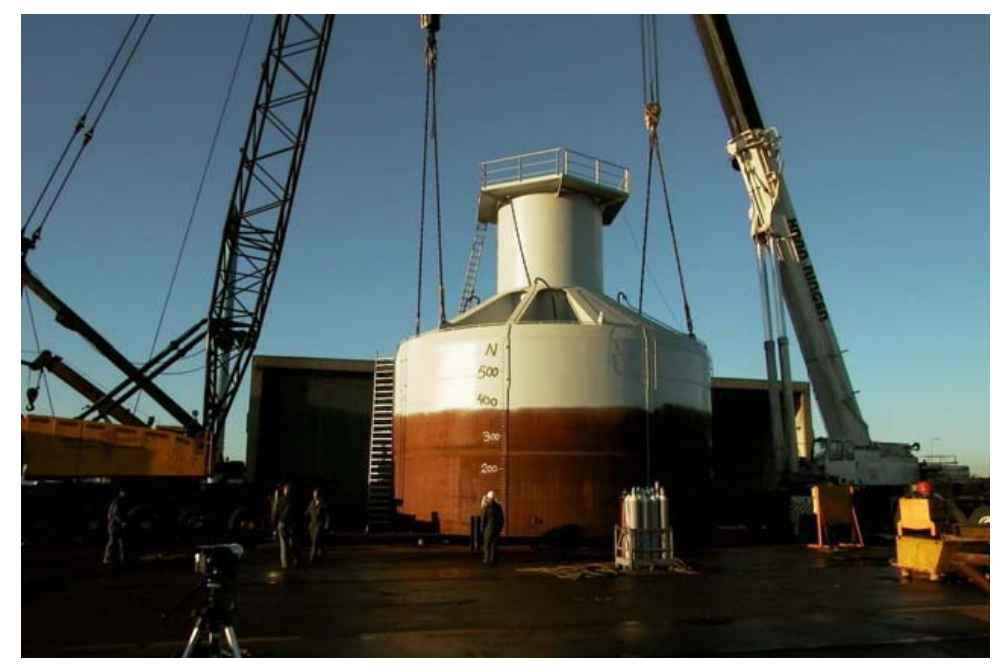

Fig. 2. Bucket foundation for the Vestas 3MW wind turbine in Frederikshavn

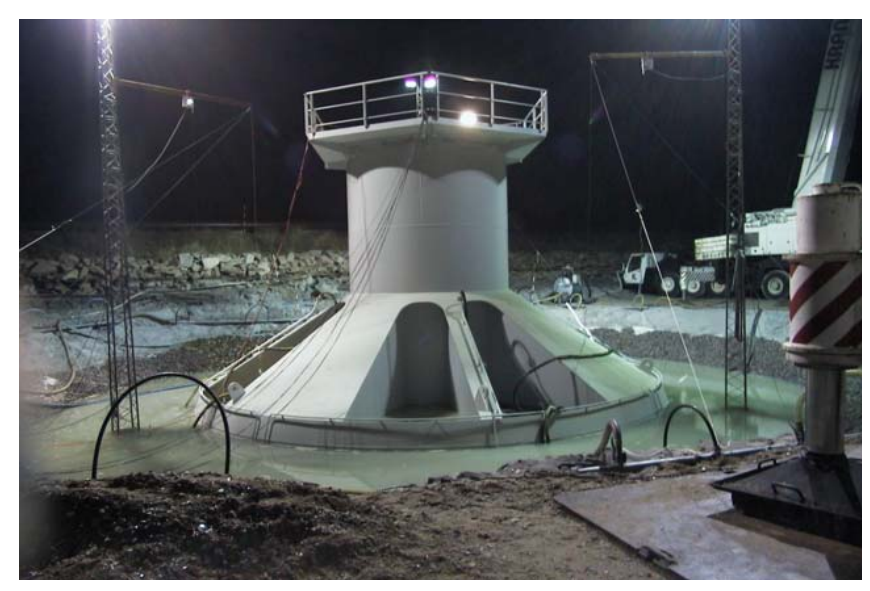

Fig. 3. Bucket foundation after installation in Nov. 2002 


\subsection{BEARING CAPACITY}

Traditional bearing capacity theory, as well as many advanced recent solutions, is based on plasticity theory. Plasticity solutions are based on the bound theorems to identify an upper and lower bound to the range within which the exact solution lies. For an answer to be exact the upper bound (mechanism) and lower bound (stress field) approaches must give the same result. Limit analysis explores different ways in which these two bounds can be satisfied until identical collapse loads are obtained with each, i.e. the true collapse load is obtained. Plasticity solutions are based on the perfect plasticity prevailing at failure, i.e. no hardening or softening behavior is considered. Although these are simple soil models, they have been widely used historically as the basis of bearing capacity solutions for both onshore and offshore applications.

\subsubsection{Undrained Bearing Capacity}

The classical recommended approach for predicting undrained bearing capacity of a shallow foundation is given by

$V_{u l t}=A^{\prime}\left(c_{u 0}\left(N_{c}+k D^{\prime} / 4\right) \frac{F K_{c}}{\gamma_{m}}+p_{0}^{\prime}\right)$

$K_{c}=1-i_{c}+s_{c}+d_{c}$

$d_{c}=0.3 e^{-0.5 k D / c_{c_{00}}} \arctan (d / D)$

The correction factor $F$ is given as a function of a dimensionless heterogeneity factor $\kappa=k D^{\prime} / c_{u 0}$. Values of $F$ as a function of $\kappa$ are shown through the work of Davis \& Booker (1973). The inclination factor $i_{c}$ and shape factor $s_{c}$ are taken directly from Brinch Hansen (1970). The inclination factor is based on the exact solution for loading of a strip foundation under a centrally applied inclined load (Green 1954) in conjunction with the effective width principle to account for moment (Meyerhof 1953). The recommended depth factor in Eq. (2) is slightly more conservative than the conventional Brinch Hansen (1970) factor. 
The undrained bearing capacity under uniaxial vertical loading of a strip foundation resting on the surface of a homogeneous deposit calculated by Eq.(1) gives $V_{u l t}=5.14 A c_{u 0}$ in agreement with the exact solution (Prandtl 1920). Incorporation of the shape factor gives $V_{u l t}=6.17 A c_{u 0}$, slightly over predicting the exact solution for a rough circular foundation of $6.05 A c_{u 0}$ (Cox et al. 1961).

\subsubsection{Drained Bearing Capacity}

The general bearing capacity formula for circular foundations reported by Terzaghi (1943) is given by:

$V_{\text {peak }}=\gamma^{\prime} \frac{D}{2} N_{\gamma}\left(\frac{\pi D^{2}}{4}\right)+q^{\prime} N_{q}\left(\frac{\pi D^{2}}{4}\right)+\frac{\pi D \gamma^{\prime} d^{2}}{2}(K \tan \delta)$

However, this equation does not include a depth factor, nor does it account for the enhanced stresses that occur due to friction along the skirt during penetration of the bucket foundation. Moreover, Eq. (3) is based on the principle of superposition, which

yields a conservative estimate of the bearing capacity that underestimates the ultimate limits for the range of foundation, soil, and loading conditions relevant offshore (Ukritchon et al. 1998; Gourvenec \& Randolph 2003; Gourvenec 2004).

\subsection{Water Penetration in Unsaturated Soils}

The Richards' expression representing the movement of water in unsaturated soils and formulated initially Lorenzo Richards in 1931, is a partial differential equation, which is often difficult to properly assess due to inherent highly nonlinearity.

The basic theories describing fluid flow through porous media were first introduced by Buckingham (1907) who realized that water flow in unsaturated soil is highly dependent on water content. Buckingham introduced the concept of "conductivity", dependent on water content, which is today known as unsaturated hydraulic conductivity (after Rolston 2007). This equation is usually known as Buckingham law (Narasimhan 2005). Buckingham also went on to define moisture 
diffusivity which is the product of the unsaturated hydraulic conductivity and the slope of the soil-water characteristic curve. Nearly two decades later, Richards (1931) applied the continuity equation to Buckingham's law - which itself is an extension of Darcy's law and obtained a general partial differential equation describing water flow in unsaturated, non-swelling soils with the matric potential as the single dependent variable (Philip 1974). There are generally three main forms of Richards' equation present in the literature namely the mixed formulation, the $h$-based formulation and the $\theta$-based formulation, where $h$ is the weight-based pressure potential and $\theta$ is the volumetric water content.

Since Richards' equation is a general combination of Darcy's law and the continuity equation as previously mentioned, the two relations must first be written in order to derive Richards' equation. Herein, one-dimensional infiltration of water in vertical direction of unsaturated soil is considered and accordingly, Darcy's law and the continuity equation are given by Eqs. (4) and (5) respectively:

$q=-K \frac{\partial H}{\partial z}=-K \frac{\partial(h+z)}{\partial z}=-K\left(\frac{\partial h}{\partial z}+1\right)$

and

$\frac{\partial \theta}{\partial t}=-\frac{\partial q}{\partial z}$

where $K$ is hydraulic conductivity, $H$ is head equivalent of hydraulic potential, $q$ is flux density and $t$ is time. The mixed form of Richards' equation is obtained by substituting Eq. (4) in Eq. (5):

$$
\frac{\partial \theta}{\partial t}=\frac{\partial}{\partial z}\left[K\left(\frac{\partial h}{\partial z}+1\right)\right]
$$




\section{OVERAL AIM AND SPECIFIC OBJECTIVES}

\subsection{RATIOANALE}

Energy production from offshore wind turbines is expected to increase significantly in the near future as offshore wind turbines become more profitable. However, the wind turbine foundations represent a large economic expense. The economic feasibility of future offshore wind farms may be increased by:

- Modifying current foundation design guidelines, which are all based on classical bearing capacity models whose applicability to offshore design is questionable.

- Characterizing the kinematic failure mechanisms for combined loadings in situations where environmental forces impose significant lateral and moment loads.

- Modeling water flow inside bucket foundations, which causes a decrease in skirt tip end bearing and is the most important contribution facilitating skirt penetration during installation.

- Developing approximate solutions for the Richards equation for unsaturated flow utilizing a novel method incorporating a convergence-control parameter.

\subsection{Overall Aim}

The overall aim was to enable the design of low-cost and low-risk support structures in order to improve the economic feasibility of future offshore wind farms, with particular emphasis on bucket foundations.

\subsection{Specific Objectives}

- To improve current design guidelines for bucket foundation bearing capacity calculations under environmental conditions producing significant lateral and 
moment loads, a subject of great importance in the field of offshore engineering.

- To demonstrate that foundation embedment must be explicitly considered in any design calculations due to the subtle interplay between the foundation geometry, the soil conditions, and the resulting failure mechanisms and loads.

- To illustrate the reduced moment load capacity of bucket foundations relative to strip foundations due to a scoop mechanism developing within the soil plug when founded on homogeneous clay.

\section{THE RESEARCH PROJECT}

The current research work reported through the Ph.D. thesis is divided into two main and important topics which are reported in four scientific papers, published in international journals or submitted for publication. An overview of the research topics as well as the publications can be found as below (Fig.4):

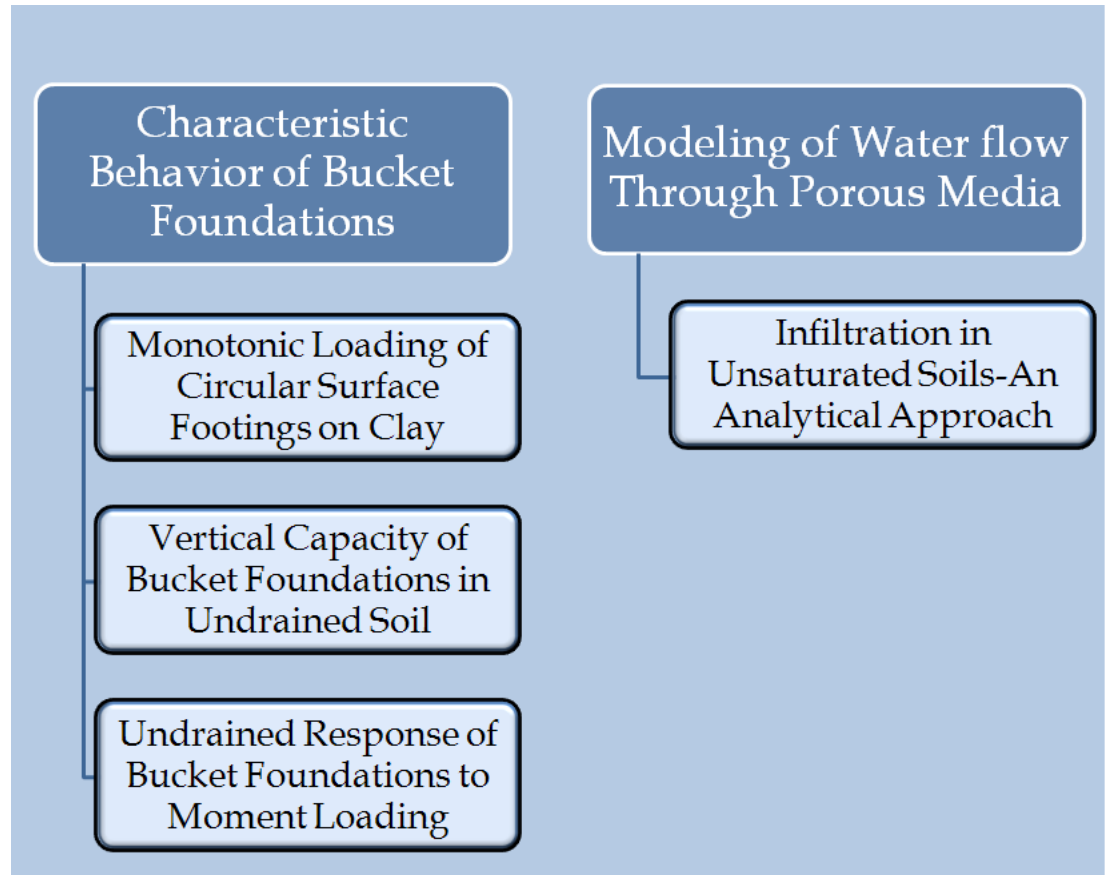

Fig. 4.Overview of the research topics and papers 
The following section presents an overview of the contents of the four papers, including background, objectives, and the approaches and methodologies utilized.

\subsection{Characteristic Behavior of Bucket Foundations}

Skirted foundations are shallow foundations in which the footing is reinforced by the addition of vertical plates, or skirts, below the footing. These skirts are normally placed around the perimeter of the foundation, but additional skirts may also be placed between the perimeter skirts. During undrained loading, the skirts are believed to improve the foundation capacity by 'trapping' the soil between them so that the foundation acts as though extended to the depth of the skirt tips (e.g. Tani \& Craig 1995).

The bearing capacity of shallow foundations has long been a topic of engineering interest. Initially, work concentrated on understanding the vertical foundation capacity, as this is the predominant foundation load due to the weight of the superstructure (Prandtl 1920; Hill 1950; Skempton 1951).

The capacity of skirted foundations under pure vertical $(V)$, moment $(M)$, or horizontal $(H)$ loads may be expressed using depth factors defining the increased resistance due to embedment with respect to a surface foundation of equivalent base area.

For vertical loading, previous research (Meyerhof 1953; Hansen 1970) has suggested that the depth factor $d_{c}$ may be approximated as a linear function of the normalized embedment depth $d / D$ as:

$d_{c}=1+n \frac{d}{D}$

where $n$ is in the range 0.2 to 0.4 . Exact solutions for the vertical bearing capacity of circular footings on uniform Tresca soil have been also proposed by Meyerhof (1951), Shield (1955), Eason \& Shield (1960), and Cox et al. (1961).

Despite the clear difference between offshore and onshore shallow foundation systems and loading conditions, the industry-recommended practice for offshore shallow foundation design (DNV 1992; API 2000; ISO 2000) was developed from onshore design codes, which is apparent in the guidelines for the individual European countries. These guidelines are based on classical bearing capacity equations for failure of a vertically 
loaded strip foundation on uniform Tresca soil (Terzaghi 1943), combined with various modification factors to account for load orientation, foundation shape, embedment, and soil strength profile.

Although some researchers have examined the behavior of bucket foundations and proposed design guidelines such as bearing capacity calculations (Ibsen et al. 2004; Achmus \& Abdel-Rahman 2005; Ibsen 2008), the full response of such structures within clay under combined loading conditions has remained relatively unexplored and in need of further research.

Paper I: "Monotonic Loading of Circular Surface Footings on Clay" and paper II: "Vertical Capacity of Bucket Foundations in Undrained Soil" address the undrained behavior of circular surface foundations and bucket foundations founded on Baltic clay possessing uniform shear strength. The circular surface foundations were designed with the same geometry as the bucket foundations. The main objective of the first work was to obtain insight into the behavior of circular foundations and to extend the model to simulate the vertical-load displacement response of offshore bucket foundations. The second work analyzed the effect of the bucket foundation geometry on the load transfer mechanism and the stress distribution within the soil as the foundations were loaded at the same strain rate as circular surface foundations. The aim of the current study is to directly investigate how variations in the embedment ratio of a foundation affect its bearing capacity. An alternative and modified expression for depth factor is recommended using a series of FE and experimental analyses.

More recent research has concentrated on understanding the foundation capacity when foundations are subjected to inclined and eccentric loading, following the initial work of Meyerhof (1953) and Hansen (1970). The problem of bearing capacity under combined loading is of particular interest in the field of offshore engineering, where environmental forces impose significant lateral and moment loads. Taiebat \& Carter (2000) studied the behavior of circular foundations on the surface of homogeneous purely cohesive soil using finite element analysis. An equation approximating the shape of the failure locus was presented.

A number of works investigating the behavior of offshore foundations exposed to combined loading (Tan 1990; Murff 1994; Butterfield \& Gotatrdi 1995; Salencon \& 
Pecker 1995; Ngo-Tran 1996) have analyzed the response of shallow foundations using the plasticity framework method rather than the traditional approach. Isotropic yield loci in $V-M-H$ space were deduced which describe the load combinations at failure for a given footing penetration. These have been proposed for several foundation systems in various soil types. A yield surface is given by

$f\left(\frac{V}{A s}, \frac{M}{A s D}, \frac{H}{A s}\right)=0$

in which $A$ is the area of the foundation, $D$ is the diameter or breadth, and $s$ represents the soil strength or effective stress.

Associated plasticity will be observed in soils obeying normality at failure and when footing detachment from the soil surface does not occur. However, when either of these conditions are violated, a separate plastic potential will be required (e.g. Tan 1990).

Paper III: "Undrained Response of Bucket Foundations to Moment Loading" addresses the experimental and numerical analyses of small-scale $(30 \mathrm{~cm}$ diameter) bucket foundation models installed on undrained soil subjected to combined loads.

The bucket foundations were exposed to moment loading via horizontal forces applied to features attached to a tower installed on the foundations. The moment load was applied to bucket foundations with several embedment ratios through arm lengths of 261, 174 , and $11 \mathrm{~cm}$. In addition, kinematic failure mechanisms were studied to demonstrate the substantial differences between bucket foundations and solid foundations, including the dramatic reduction in capacity due to an internal "inverted" scoop mechanism developing within the soil plug and the coupling between horizontal translation and rotational degrees of freedom for various geometries.

Finally, the Murff (1994) expression (Eq. 9) was employed to seek the yield surfaces in the $V-M-H$ coordinate system:

$$
f=\left(\frac{V}{V_{0}}\right)^{2}-\left(1+\frac{V_{t}}{V_{0}}\right) \frac{V}{V_{0}}+\frac{V_{t}}{V_{0}}+\left[\left(\frac{H}{H_{0}}\right)^{2}+\left(\frac{M}{M_{0}}\right)^{2}\right]^{0.5}=0
$$

Let $V_{t}=-V_{0}$ (Watson \& Randolph 1997). The Murff equation is then simplified to: 
$f=\left(\frac{V}{V_{0}}\right)^{2}-1+\left[\left(\frac{H}{H_{0}}\right)^{2}+\left(\frac{M}{M_{0}}\right)^{2}\right]^{0.5}=0$

This research led to three publications, an overview of which may be found in Figs. 5-7.

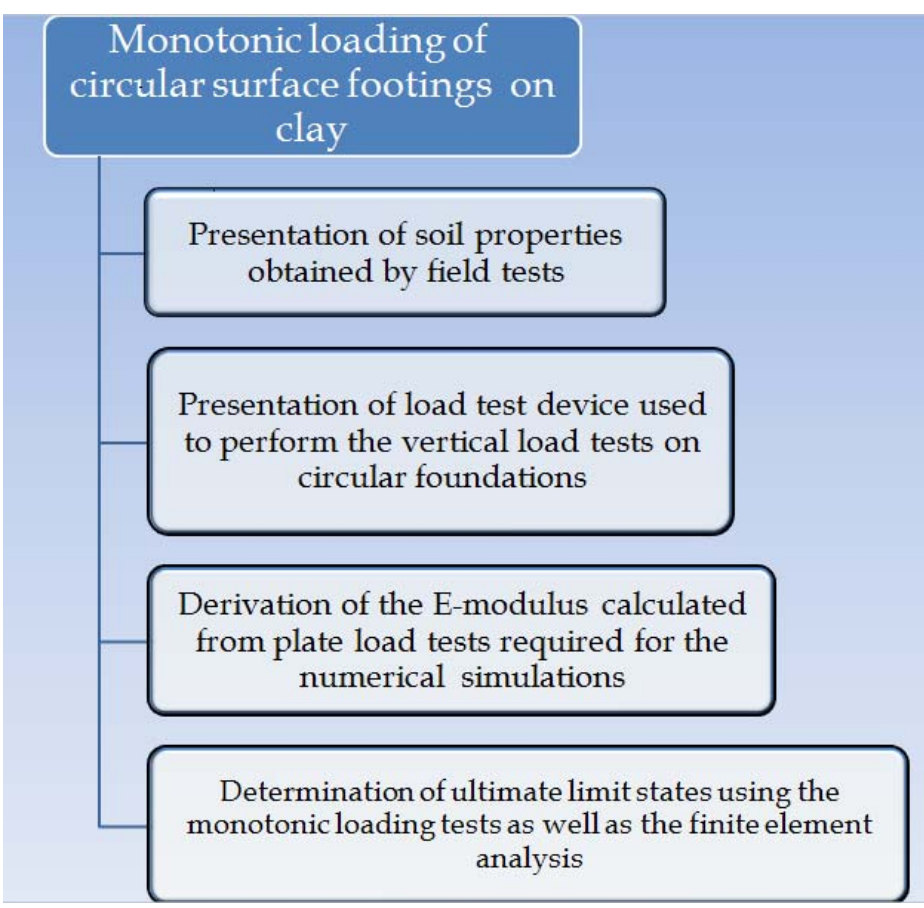

Fig. 5. Overview of paper I 


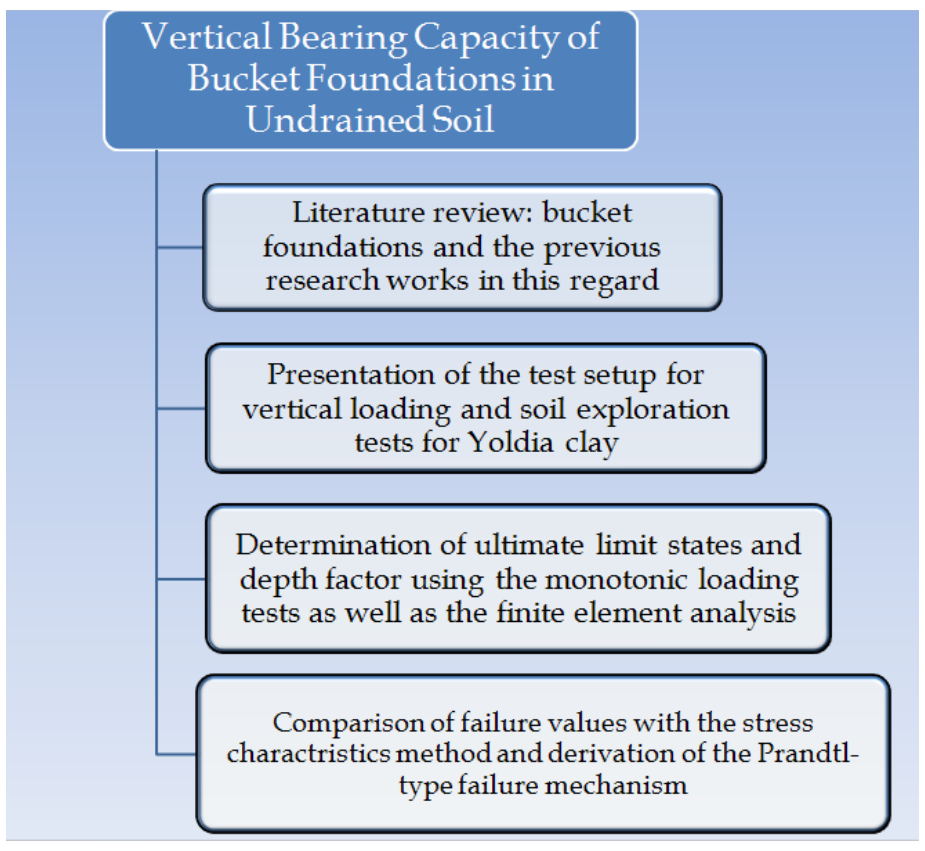

Fig. 6. Overview of paper II

\section{Undrained Response of Bucket \\ Foundations to Moment Loading}

Outline of the problem related to the combined capacity of bucket foundations and highlighting the main contributions of the work

Performing the tests for three cases considering the effect of combination of horizontal and rotational deformations and finding the ultimate limit states

Presentation of the experimental results and kinematic failure mechanisms including scoop and sliding mechanisms due to the coupling of the horizontal and moment degrees of freedom

Derivation of yield surfaces for bucket foundations under combined loadings based on the ultimate limit states and Murff's expression

Fig. 7. Overview of paper III 


\subsection{Modeling of Water Flow Through Porous Media}

Modeling of water flow through porous media presents an important problem of practical interest for geotechnical and geo-environmental engineering, as well as many other areas of science and engineering. Study of this phenomenon requires proper formulation of the governing equations and constitutive relations involved. Current equations used for describing fluid flow through porous media are mainly based on semiempirical equations first derived by Buckingham and Richards. Specifically, despite limitations and drawbacks, Richards' equation is still the most widely used equation for modeling unsaturated flow of water through soil (porous media) (Hoffmann 2003). Due to the importance and wide applications of the problem, many researches have been devoted in the past to proper assessment of different forms of Richards' equation. Both analytical and numerical solutions have been investigated in the literature. Analytical solutions to Richards' equation are rather scarce and are generally limited to only special cases (Ju \& Kung 1997; Arampatzis et al. 2001). This is mainly due to the dependence of hydraulic conductivity and diffusivity - two important parameters in the equation - on moisture content, combined with the non-trivial forcing conditions that are often encountered in engineering practice (Ju \& Kung 1997; Arampatzis et al.2001; Kavetski et al. 2002). As a result, application of many numerical methods to the solution of Richards' equation with various engineering applications has been investigated in the literature. Finite element and finite difference methods have been adopted by several researchers (Clement et al. 1994; Baca et al. 1997; Bergamaschi \& Putti 1999; Milly 1985). Mass lumping was employed in these studies to improve stability. Time stepping schemes such as the Douglas-Jones-predictor-corrector method, Runge-Kutta method and backward difference formulae should also be mentioned in this context (Kavetski et al. 2001; Miller et al. 2005). Tabuada et al. (1995) used an implicit method and presented equations governing two-dimensional irrigation of water into unsaturated soil based on Richards' equation. The Gauss-Seidel method was then effectively used to solve the resulting equations. Ross (2003) introduced an efficient non-iterative solution for Richards' equation using soil property descriptions as proposed by Brooks \& Corey (1964). In his method, Ross used a space and time discretization scheme in order to 
derive a tridiagonal set of linear equations which were then solved non-iteratively. Varado et al. (2006) later conducted a thorough assessment of the method proposed by Ross and concluded that the model provides robust and accurate solutions as compared with available analytical solutions (Basha 1999). Several other iterative solutions have also been cited in the literature. One such study is that of Farthing et al. (2003) which used the well-known pseudo-transient continuation approach to solve the nonlinear transient water infiltration problem, as well as the steady-state response as governed Richards' equation. Other commonly used iterative schemes include the Picard iteration scheme (Chounet et al. 1999; Forsyth et al. 1995), the Newton and inexact Newton schemes (Jones and Woodward 2001; Kavetski et al. 2001; Kees \& Miller 2002) and hybrid Newton-Picard methods. Huang et al. (1996) considered the modified Picard iteration schemes and presented several convergence criteria as to evaluate the efficiency of the various iterative methods. In geo-environmental applications, Bunsri et al. (2008) solved Richards' equation accompanied by advective-dispersive solute transport equations by the Galerkin technique. Witelski (1997) used perturbation methods to study the interaction of wetting fronts with impervious boundaries in layered soils governed by Richards' equation. Through comparison with numerical solutions, Witelski concluded that perturbation methods are able to yield highly accurate solutions to Richards' equation (Witelski 1997).

Often, assumptions are made and empirical models are implemented in order to overcome difficulties in solving the equation due to high interdependence of some of the parameters involved. Analytical solutions often fit under classical perturbation methods (Nayfeh 1973). However, as with other analytical techniques, certain limitations restrict the wide application of perturbation methods, most important of which is the dependence of these methods on the existence of a small parameter in the equation. Disappointingly, the majority of nonlinear problems have no small parameters at all. Even in cases where a small parameter does exist, the determination of such a parameter does not seem to follow any strict rule, and is rather problem-specific. Furthermore, the approximate solutions solved by the perturbation methods are valid, in most cases, only for the small value ranges of the parameters. It is obvious that all these limitations come from the small parameter assumption. In order to overcome the shortcomings, many new techniques 
have appeared in the literature such as; Harmonic Balance (Hamdan \& Shabaneh 1997), Modified Lindstedt-Poincaré (Ozis \& Yildirim 2007), Artificial Parameter LindstedtPoincaré (Ramos 2009), Adomian Decomposition (Wang et al. 2008; Mirgolbabaei et al. 2010), Parameter-Expansion (Kimiaeifar et al. 2011), Frequency Amplitude Formulation (Fereidoon et al. 2011), Parametrized Perturbation (Barari et al. 2011), Multiple Scale (Okuizumi \& Kimura 2004), Energy Balance (Sfahani et al. 2011; Bayat et al. 2011), Variational Iteration (Barari et al. 2008a, 2008b), Newton-Harmonic Balancing (Lai et al. 2009), Differential Transformation (Catal 2008; Omidvar et al. 2010), Max-Min (Sfahani et al. 2010; Ibsen et al. 2010), Homotopy Analysis Method (HAM) (Liao 2004; Ghasemi et al. 2012).

Paper IV "Infiltration in Unsaturated Soils - An Analytical Approach" approximates the solution for Richards' problem modeling the unsaturated flow of transports in soils emplying the Homotopy Analysis Method (HAM). The method is superior over traditional perturbation techniques in a sense that it is not dependent on the assumption of a small parameter as the initial step. Several cases have been explored to describe the application of HAM to Richards' equation. The results obtained by HAM are also compared with existing solutions to demonstrate the accuracy of the proposed method.

An overview of the contents and outcomes of the proposed research topic is reported in Fig.8. 


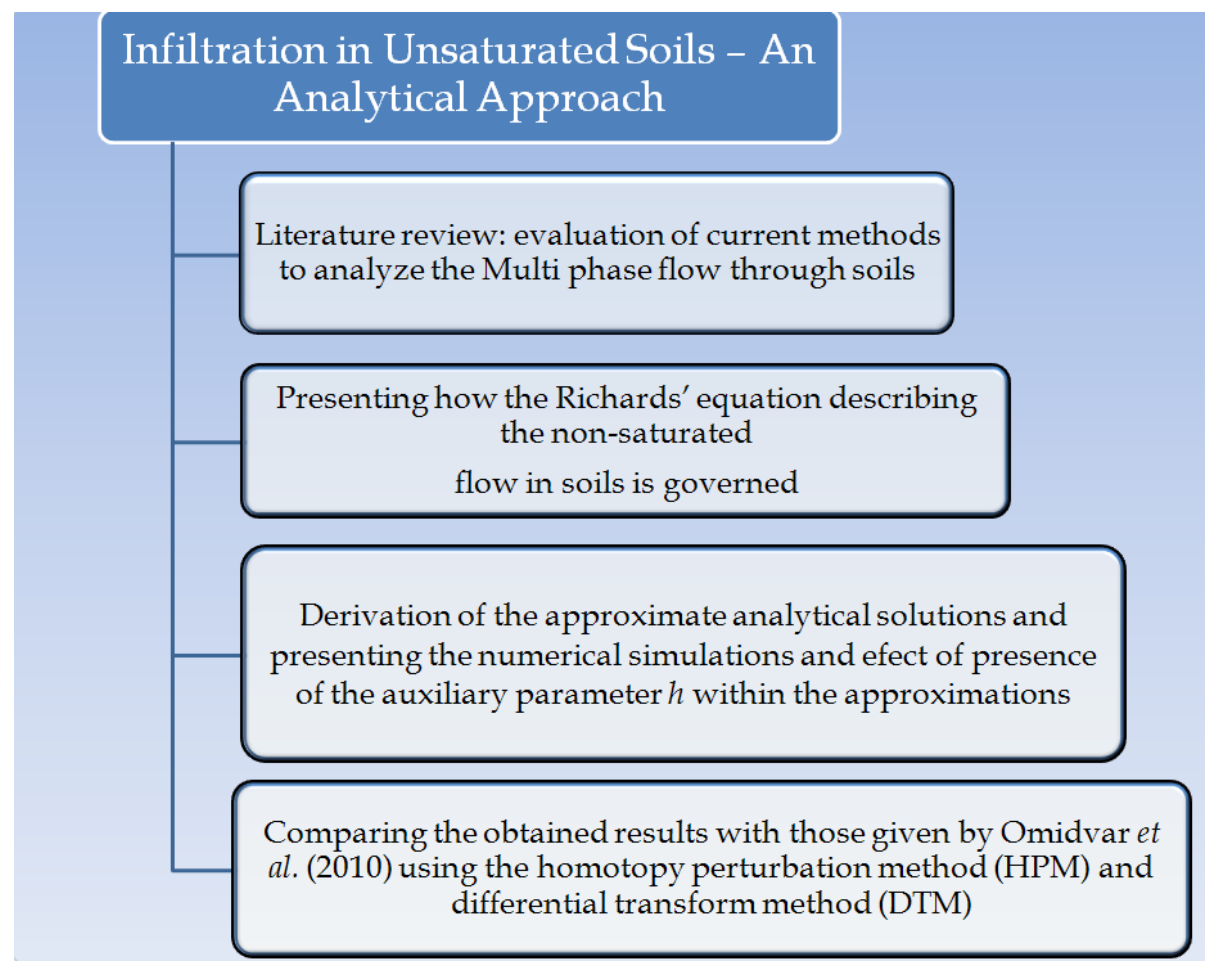

Fig. 8. Overview of the paper IV

\section{CONCLUSIONS AND RECOMMENDATIONS FOR FUTURE RESEARCH}

The topics presented here are intended to improve the design of future offshore wind turbine foundations. The work has been divided in two main research categories in the field of offshore geotechnics. The research topics were targeted to gain insight into the behavior of offshore bucket foundations and to provide better means of studying infiltration into unsaturated soils, an important problem in geo-environmental engineering. Overall, the outcomes presented in this thesis may reduce the risks and costs related to offshore geotechnics and thereby contribute to increasing the economic feasibility of future offshore projects.

In this chapter, the main outlines, contributions, and conclusions of the research projects are reported and recommendations for future projects are suggested. 


\subsection{Characteristic Behavior of Bucket Foundations}

A set of comprehensive experimental and numerical investigations was carried out to develop design guidelines for the bearing capacity of bucket foundations. These fundamental investigations were presented in three research articles entitled: "Monotonic Loading of Circular Surface Footings on Clay", "Vertical Capacity of Bucket Foundations in Undrained Soil," and "Undrained Response of Bucket Foundations to Moment Loading."

\subsubsection{Monotonic Loading of Circular Surface Footings on Clay}

The major contribution of the first article was to establish the experimental and numerical simulations needed to analyze the effect of the geometry of circular surface footings on the load transfer mechanism within the soil, and to extend the model to investigate the undrained response of offshore bucket foundations.

The analyses were supported by data from 6 plate load tests using foundation diameters of 20 and $30 \mathrm{~cm}$. A CPT apparatus was inserted into the soil at a hydraulic velocity of $1.2 \mathrm{~m} / \mathrm{min}$. A penetration depth of approximately $3 \mathrm{~m}$ was obtained using 3 rods. This penetration depth was chosen because the subsoil contained of large quantities of sand. The load test device developed for vertical load tests on circular surface footings consisted of 2 vertical legs $1.5 \mathrm{~m}$ in height. The legs were anchored into the soil to a depth of approximately $1.5 \mathrm{~m}$ and two horizontal beams with a span of $2.25 \mathrm{~m}$ were placed on the legs.

The results of the six plate load tests (denoted 300P-1, 300P-2, 300P-3, 200P-5, 200P-6, and 200P-7) revealed that the stress-displacement curves were almost identical for 200P-6 and 200P-7 to a deformation of nearly $15 \mathrm{~mm}$. Moreover, the force required to produce deformations relative to the failure condition in the $200 \mathrm{P}-5$ trial was similar to those in 200P-6 and 200P-7. The results of 300P-1 differed slightly from those of 300P-2 and 300P-3. In the first test the curve continued to grow, whereas in the latter two tests the curves began to flatten out. The failure values, deformations, and $E$ values for 20 and 
$30 \mathrm{~cm}$ diameter circular surface footings under vertical loading were determined from the tests.

The mechanical properties of the clay were obtained from laboratory tests of field samples. The properties were varied in numerical parametric analyses to investigate their effect on the bearing capacity of the footings.

\subsubsection{Vertical Capacity of Bucket Foundations in Undrained Soil}

Within the second work, comprehensive investigations conducted at Aalborg University were used to develop design guidelines for the behavior of offshore bucket foundations in response to monotonic loading.

In order to examine the effect of foundation geometry, to present a methodology capable of properly addressing the increased bearing capacity due to existence of embedment, and to describe an alternative to the traditional depth factor relationships, bucket foundations with diameters of 20 and $30 \mathrm{~cm}$ and embedment ratios of $0.25,0.50$, 0.75 , and 1 were tested. The soil at the test site was composed of Yoldia clay (often referred to as Baltic clay) which to a depth of approximately $2 \mathrm{~m}$ consisted of brownishgray clay containing a large amount of silt as well as sand and chalk in horizontal stripes approximately $1 \mathrm{~mm}$ thick.

The foundations were installed by applying pressure to the top of the bucket using a hydraulic cylinder to ensure penetration at a predefined rate of $1.4 \mathrm{~mm} / \mathrm{s}$. Loading of the bucket continued until the bucket skirt fully penetrated the soil and the top plate was in contact with the ground surface. The installation rate was similar to the rate employed for previous tests on circular models on Aalborg University sand No.1 (Ibsen et al.2012).

The ultimate limit states determined for the bucket foundations were compared with the plasticity stress characteristic values presented by Houlsby \& Wroth (1983) as well as the exact solutions proposed by Shield et al. (1955) and the finite element results of Gourvenec \& Randolph (2002) for embedment ratios from 0 to $d / D=0.5$.

The variation in normalized vertical limit state $\left(N_{c V}=\left(\frac{V_{u t}}{D c_{u}}\right)\right)$ with respect to embedment ratio for bucket foundations and a comparison with previous numerical 
works in the literature (Bransby and Randolph (1999) and Gourvenec (2008)) were also reported.

The main conclusions are summarized below:

- Numerical simulations were used to study how variations in soil modulus affect the ultimate limit states. Values of $25 \%, 30 \%, 40 \%$, and $50 \%$ and the tangent elastic modulus corresponding to $25 \%$ strain $E_{25}$ were selected to obtain the best agreement with the field data.

- Variation of the skirt length had little effect on the bearing capacity in all vertical loading experiments except those using a $20 \mathrm{~cm}$ bucket with an embedment ratio of 0.5 .

- Although Tani and Craig (1995) used the results of lower bound plasticity analyses and centrifuge tests of skirted foundations to suggest that the vertical capacity is independent of either the soil strength above the level of the base of the footing or embedment effects for undrained conditions, this finding has not been verified using vertical monotonic loading or finite element analysis, and a $37 \%$ increase in pure bearing capacity for the two samples ranging from $d / D=0$ to $d / D=0.5$ was observed.

- A modified quadratic relationship between the ultimate uniaxial vertical load and the embedment ratio in terms of depth factor is recommended.

It is also recommended that the influence of shear strength heterogeneity described by Eq. (11) on the behavior of bucket foundations be considered in future research.

$\kappa=\frac{k D}{S_{u 0}}$

For a shallow foundation with skirt depth $d$, the shear strength at foundation level is $S_{u 0}=S_{u m}+k d$, where $S_{u m}$ and $k$ are the shear strength at the mudline and the strength gradient with depth $z$. 


\subsubsection{Undrained Response of Bucket Foundations to Moment Loading}

Design guidelines for calculating the bearing capacity of offshore shallow foundations are set out by ISO (2000), DNV (1992), and API (2000), among others. Despite the clear difference between offshore and onshore shallow foundation systems and loading conditions, the roots of the design methods presented in the recommended practices are the same as those adopted for onshore design, which are entirely based on the classical bearing capacity theory of Terzaghi (Terzaghi 1943).

The major contribution of this paper is an analysis of how general loading of bucket foundations results in a complex state of stress in homogeneous soil. It is becoming increasingly accepted that when horizontal and moment loads are applied in combination with vertical loads, the interaction of these different components should be explicitly considered when determining the bearing capacity (as opposed to the coupling of solutions using inclination and eccentricity factors adopted in the classical bearing capacity approach).

Experiments were conducted using Yoldia clay, the predominant soil at the Aalborg University clay test site. The buckets were $30 \mathrm{~cm}$ in diameter. The foundations were tested using embedment ratios of $0.25,0.50,0.75$, and 1 . The experimental arrangement for moment load testing was different from the vertical loading configuration. The experimental area was reduced from $180 \times 150 \mathrm{~cm}^{2}$ to approximately $150 \times 150 \mathrm{~cm}^{2}$. The average installation rate was $1.4 \mathrm{~mm} / \mathrm{sec}$. The buckets were pressed into the clay until the bucket top plate reached the soil plug. For moment loading tests, the loads were applied via features attached to a tower installed on the foundations.

Arm lengths of 261, 174, and $11 \mathrm{~cm}$ were tested to investigate the influence of the $M / H$ stress path on the failure modes. The main conclusions are summarized below:

- Two different loading features were employed in the experiments due to the fact that the center of rotation was close to the loading height. The apparatus was modified for tests at the $11 \mathrm{~cm}$ loading height.

- During the tests, failure lines were observed in the ground surface around the top plate. These were caused by a combination of horizontal and rotational 
deformations, and the appearance of the lines was dependent on the skirt length and the loading path $(M / H)$.

- A comparison of ground deformations due to moment effects between the skirt lengths reveals that the influence of the soil surface becomes smaller as the skirt length increases.

- The ultimate horizontal load capacity of skirted foundations is governed by a translational scoop mechanism (as opposed to pure sliding) due to coupling of the horizontal and moment degrees of freedom.

- Some shearing was also observed between the skirts, contrary to the mechanisms observed in skirted strip foundations (Bransby and Yun 2009) subjected to purely horizontal loads.

- The failure mechanisms for bucket foundations are substantially different from solid foundations in that the capacity may be dramatically reduced due to an internal "inverted" scoop mechanism developing within the soil plug. This reduction in capacity becomes less significant with increasing embedment ratio.

- The modified form of the Murff (1994) expression employing the assumption of Watson and Randolph (1997) that $V_{t}=-V_{0}$ was utilized for analyzing the combined loading response of shallow foundations used in offshore engineering.

- Bucket foundations may have less capacity than equivalent solid foundations due to the existence of an internal scoop mechanism inside the bucket. This finding has serious implications for bucket foundation design. Bucket foundations should not be designed as if solid unless only the vertical capacity is being considered.

General loading is of particular interest offshore, where harsh environmental conditions lead to large horizontal and moment foundation loads. Future research should further address the complex interaction of vertical, horizontal, and moment (VHM) loads acting on bucket foundations, focusing on proper representation of the 
failure envelopes for undrained ultimate limit states in uniform and heterogeneous deposits in three-dimensional load space.

\subsection{Modeling of Water Flow through Porous Media}

The $h$-based formulation of Richards' equation is obtained as below:

$C(h) \times \frac{\partial h}{\partial t}=\frac{\partial}{\partial z}\left(K \frac{\partial h}{\partial z}\right)+\frac{\partial K}{\partial z}$

This is a fundamental equation in geotechnical engineering and is used for modeling flow of water through unsaturated soils. For instance, the equation above can be used to model the steady state seepage flow in the soil during installation of bucket foundations. The effect of this seepage flow is to increase the external friction whilst the internal friction is decreased. More importantly though, the skirt tip end bearing is also decreased and this is most important contribution facilitating skirt penetration.

Introducing a new term $D$, pore water diffusivity defined as the ration of the hydraulic conductivity and the differential water capacity, the $\theta$-based form of Richards' equation may be obtained. $D$ can be written as:

$D=\frac{K}{C}=\frac{K}{\frac{\mathrm{d} \theta}{d h}}=K \frac{\mathrm{d} h}{d \theta}$

It should be noted that both $D$ and $K$ are highly dependent on water content. The Richards' equation is then given as:

$\frac{\partial \theta}{\partial t}=\frac{\partial}{\partial z}\left(D \frac{\partial \theta}{\partial z}\right)+\frac{\partial K}{\partial z}$

In order to solve Eq. (14), one must first address the task of estimating $D$ and $K$, both of which are dependent on water content. Several models have been suggested for determining these parameters. The Van Genuchten model (Van Genuchten 1980) and Brooks and Corey's model (Corey 1994) are the more commonly used models. The Van Genuchten model uses mathematical relations to relate soil water pressure head with water content and unsaturated hydraulic conductivity, through a concept called "relative saturation rate". This model matches experimental data but its functional 
form is rather complicated and it is therefore difficult to implement it in most solution schemes. Brooks and Corey's model on the other hand has a more precise definition and is therefore adopted in the present research. This model uses the following relations to define hydraulic conductivity and water diffusivity:

$D(\theta)=\frac{K_{s}}{\alpha \lambda\left(\theta_{s}-\theta_{r}\right)}\left(\frac{\theta-\theta_{r}}{\theta_{s}-\theta_{r}}\right)^{2+\frac{1}{\lambda}}$

$K(\theta)=K_{s}\left(\frac{\theta-\theta_{r}}{\theta_{s}-\theta_{r}}\right)^{3+\frac{2}{\lambda}}$

where $K_{s}$ is saturated conductivity, $\theta_{r}$ is residual water content, $\theta_{s}$ is saturated water content and $\alpha$ and $\lambda$ are experimentally determined parameters. Brooks and Corey determined $\lambda$ as pore-size distribution index. A soil with uniform pore-size possesses a large $\lambda$ while a soil with varying pore-size has small $\lambda$ value. Theoretically, the former can reach infinity and the latter can tend towards zero. Further manipulation of Brooks and Corey's model by replacing the model parameters of Eqs. (15) and (16) with experimentally developed parameters yields the following equations (Witelski 2005):

$D(\theta)=D_{0}(n+1) \theta^{m} \quad m \geq 0$

$K(\theta)=K_{0} \theta^{k} \quad k \geq 1$

where $K_{0}, D_{0}$ and $k$ are constants representing soil properties such as pore-size distribution, particle size, etc, while $n$ and $m$ are constants as mentioned by Witelski (2005). In this representation of $D$ and $K, \theta$ is scaled between 0 and 1 and diffusivity is normalized so that for all values of $m, \int D(\theta) d \theta=1$.

Several analytical and numerical solutions to Richards' equation exist based on Brooks and Corey's representation of $D$ and $K$. Replacing $n=0$ and $k=2$ in the equations above yields the classic Burgers' equation extensively studied by many researchers (Basha 2002; Broadbridge \& Rogers 1990). The generalized Burgers' equation is also obtained for general values of $k$ and $m$ (Grundy 1983).

As seen previously, the two independent variables in Eq. (14) are time and depth. By applying the traveling wave technique (Elwakil et al. 2004; Soliman et al. 2006), instead of time and depth, a new variable which is a linear combination of them is found. 
Tangent-hyperbolic function is commonly applied to solve these transform equations (Abdou \& Soliman 2006). Therefore the general form of Burgers' equation in order of $(\mathrm{n}, 1)$ is obtained as (Wazwaz 2005):

$\theta_{t}+\alpha \theta^{n} \theta_{z}-\theta_{z z}=0$

The fourth paper entitled "Infiltration in Unsaturated Soils-An Analytical Approach" presents the results of approximate analytical solutions to Richards' equation. The existing methods generally fall within the category of numerical and analytical methods, often having many restrictions for practical situations. In the present study, a novel approximate analytical method known as the Homotopy Analysis Method (HAM) was developed to approximate the Richards' equation. The method was found to be robust in finding solutions practically identical to those from the existing solutions. Two representative examples were considered in order to evaluate the accuracy of the solutions obtained by HAM, revealing high level of accuracy in both cases.

Omidvar et al. (2010) proposed two approximate solutions for the mentioned problem using Homotopy Perturbation Method (HPM) and Differential Transform Method (DTM). DTM is a straight forward method in the form of a polynomial for solving differential equations initially introduced by Zhou (1986), reducing the size of computational volume compared to the Taylor series method. Indeed, it is found that using HPM and DTM yield a non converging series to the problem under consideration as time elapses. However, convergence is adequately achieved within the HAM results due to the presence of the convergence-control parameter.

Further research should also investigate the two-dimensional form of the Richards' equation as one of the most applicable problems in Geohydrology modeling for instance seepage in the unsaturated zone above water table in an earth dam. Because of the limitations in solving such equations analytically the exploration of plausible solutions to highly nonlinear systems has always been an ongoing challenge for scientists and engineers. It is therefore suggested to approximate higher orders of the Richards' problem in the future research. 


\title{
Nomenclature
}

\author{
$V_{u l t} \quad$ ultimate vertical load \\ $A^{\prime} \quad$ effective bearing area of the foundation \\ $c_{u 0} \quad$ undrained shear strength of the soil at foundation level \\ $N_{c} \quad$ bearing capacity factor for vertical loading of a strip \\ foundation on a homogeneous deposit, i.e. 5.14 (Prandtl
}

1920)

$k \quad$ Gradient of the undrained shear strength profile (equal to

zero for homogenous deposits)

$D^{\prime} \quad$ effective width of the foundation (Meyerhof 1953)

F correction factor to account for the degree of strength

heterogeneity

$\gamma_{m} \quad$ material factor on shear strength

$K_{c} \quad$ modification factor to account for load orientation, foundation shape and embedment

$i_{c} \quad$ dimensionless factor for load inclination

$S_{c} \quad$ shape factor

$d_{c} \quad$ depth factor

d skirt length

$K \quad$ coefficient of lateral earth pressure

$\delta \quad$ friction angle between skirt and surrounding soil

$p_{0}^{\prime} \quad$ effective overburden

$\gamma^{\prime} \quad$ effective unit weight of the soil

$N_{\gamma}, N_{q} \quad$ bearing capacity factors for self-weight and surcharge 


\section{LITERATURE CITED}

Abdou, M.A. \& Soliman, A.A. (2006). Modified extended Tanh-function method and its application on nonlinear physical equations. Physics Letters A 353, 487-492.

Achmus, M. \& Abdel-Rahman, K. (2005). Design of monopile foundations for offshore wind energy plants. Proc. 11th International Coloquium on Structural and Geotechnical Engineering, Cairo, Egypt.

API. (2000). RP2A: Recommended practice for planning, designing and construction fixed offshore platforms. American Petroleum Institute, Washington, DC.

Arampatzis, G., Tzimopoulos, C., Sakellariou-Makrantonaki, M. \& Yannopoulos, S. (2001). Estimation of unsaturated flow in layered soils with the finite control volume method, Irrigation and drainage 50, 349-358.

Baca, R.G., Chung, J.N. \& Mulla, D.J. (1997). Mixed transform finite element method for solving the nonlinear equation for flow in variably saturated porous media. International Journal for Numerical Methods in Fluids 24, 441-455.

Basha, H.A. (1999). Multidimensional linearized nonsteady infiltration with prescribed boundary conditions at the soil surface. Water Resources Research 25, No.1, 5-93.

Basha, H.A. (2002). Burger's equation: a general nonlinear solution of infiltration and redistribution. Water Resource Research 38, No. 11, 291-299.

Barari, A., Omidvar, M., Ghotbi, Abdoul R. \& Ganji, D.D. (2008a), Application of homotopy perturbation method and variational iteration method to nonlinear oscillator differential equations. Acta Applicanda Mathematicae 104, No.2,161-171.

Barari, A., Omidvar, M., Ganji, D.D. \& Tahmasebi Poor, A. (2008b). An approximate solution for boundary value problems in structural engineering and fluid mechanics. Journal of Mathematical Problems in Engineering, Article ID 394103, 1-13.

Barari, A., Kaliji, H.D., Ghadimi, M. \& Domairry, G. (2011). Non-linear vibration of Euler-Bernoulli beams. Latin American Journal of Solids and Structures 8, No.2, 139-148.

Bayat, M., Barari, A. \& Shahidi, M. (2011), Dynamic response of axially loaded EulerBernoulli beams. Mechanika 7, No. 2, 172-177. 
Bergamaschi, L. \& Putti, M. (1999). Mixed finite element and Newton-type linearizations for the solution of Richards' equation. International Journal for Numerical Methods in Engineering 45, 1025-1046.

Bransby, M. F.\& Randolph, M. F. (1999). The effect of skirted foundation shape on response to combined V-M-H loadings. International Journal of Offshore and Polar Engineering 9, No. 3.

Bransby, M.F. \& Yun, G.J. (2009). The undrained capacity of skirted strip foundations under combined loading. Geotechnique 59, 115-125.

Brinch Hansen, J. (1970). A revised and extended formula for bearing capacity. The Danish Geotechnical Institute, Copenhagen, 98, 5-11.

Broadbridge, P. \& Rogers, C. (1990). Exact solution for vertical drainage and redistribution in soils. Journal of Engineering Mathematics 24, No. 1, 25-43.

Brooks, R.H. \& Corey, A.T. (1964). Hydraulic properties of porous media. Hydrology paper 3, Colorado State University, Fort Collins.

Buckingham, E. (1907). Studies on the movement of soil moisture. Bulletin 38, USDA Bureau of Soils, Washington, DC, USA.

Bunsri, T., Sivakumar, M. \& Hagare, D. (2008). Numerical modeling of tracer transport in unsaturated porous media. Journal of Applied Fluid Mechanics 1, No. 1, 62-70.

Butterfield, R. \& Gottardi, G. (1995). Simplifying transformations for the analysis of shallow foundations on sand. Proc. 5th Int. Offshore and Polar Engrg. Conf., The Hauge, 534-538.

Catal, S. (2008). Solution of free vibration equations of beam on elastic soil by using differential transform method. Applied Mathematical Modeling 32, No. 9, 17441757.

Chounet, L.M., Hilhorst, D., Jouron, C., Kelanemer, Y. \& Nicolas, P. (1999). Simulation of water flow and heat transfer in soils by means of a mixed finite element method. Advances in Water Resources 22, No.5, 445-60.

Clement, T. P., William, R.W. \& Molz, F.J. (1994). A physically based two-dimensional, finite-difference algorithm for modeling variably saturated flow. Journal of Hydrology 161, 71-90. 
Corey, A.T. (1994). Mechanics of immiscible fluids in porous Media. Highlands Ranch, Water Resource Publications, p.252.

Cox, A.D., Eason, G. \& Hokins, H.G.(1961).Axially symmetric plastic deformation in soils. Philosophical Transactions of the Royal Society of London, Series A 254, 145.

Davis, E.H. \& Booker, J.R. (1973).The effect of increasing strength with depth on the bearing capacity of clays. Geotechnique 23, No.4, 551-563.

DNV. (1992). Classification notes No. 30.4, Foundations. Det Norske Veritas.

Eason, G. \& Shield, R. T. (1960). The plastic indentation of a semi-infinite solid by a perfectly rough circular punch. J. Appl. Math. Phys. (ZAMP) 11, No. 1, 33-43.

Elwakil, S.A., El-Labany, S.K., Zahran, N.A. \& Sabry, R. (2004). Exact traveling wave solutions for diffusion-convection equation in two and three spatial dimensions. Computational Physics Communication 158, 113-116.

Farthing, M.W., Kees, C.E., Coffey, T.S., Kelley, C.T. \& Miller, C.T. (2003). Efficient steady-state solution techniques for variably saturated groundwater flow. Advances in Water Resources 26, No. 8, 833-849.

Fereidoon, A., Ghadimi, M., Barari, A., Kaliji, H.D. \& Domairry, G. (2011). Nonlinear vibration of oscillation systems using frequency amplitude formulation. Shock and vibration, DOI: 10.3233/SAV20100633.

Forsyth, P.A., Wu, Y.S. \& Pruess, K. (1995). Robust numerical methods for saturatedunsaturated flow with dry initial conditions in heterogeneous media. Advances in Water Resources 18, No. 1, 25-38.

Ghasemi E., Soleimani, S., Barari, A., Bararnia, H. \& Domairry G. (2012). The influence of uniform suction/injection on heat transfer of MHD Hiemenz flow in porous media. J. Engineer. Mech. ASCE 138, No.1, 82-88.

Gourvenec, S. M. (2004). Bearing capacity under combined loading: a study of the effect of shear strength heterogeneity. Proc. 9th Australia New Zealand Conf. on Geomechanics, Auckland, 527-533.

Gourvenec, S. (2008). Effect of embedment on the undrained capacity of shallow foundations under general loading. Geotechnique 58, 177-185. 
Gourvenec, S. \& Randolph, M. R. (2003). Failure of shallow foundations under combined loading. Proc. 13th Eur. Conf. Soil Mech. Geotech. Engng, Prague, 583588.

Gourvenec, S., \& Randolph, M. (2002). Effect of strength non-homogeneity on the bearing capacity of circular skirted foundations subjected to combined loading. Proceedings of the Twelfth International Offshore and Polar Engineering Conference, Kitakyushu, Japan, 26-31.

Green, A.P. (1954). The plastic yielding of metal junctions due to combined shear and pressure. J.Mech. Phys. Solids 2, No.3, 197-211.

Grundy, R.E. (1983). Asymptotic solution of a model nonlinear convective diffusion equation. IMA Journal of Engineering Mathematics 31, No. 2, 121-137.

Hamdan, M.N. \& Shabaneh, N.H. (1997). On the large amplitude free vibrations of a restrained uniform beam carrying an intermediate lumped mass. Journal of Sound and Vibration 199, No.5, 711-736.

Hansen, B. J. (1970). A revised and extended formula for bearing capacity. The Danish Geotechnical Institute, Copenhagen 98, 5-11.

Hill, R.(1950). The mathematical theory of plasticity. Oxford, Clarenden Press.

Hoffmann, M. R. (2003). Macroscopic equations for flow in unsaturated porous media. Ph.D. dissertation, Washington University.

Houlsby, G.T., Ibsen, L.B. \& Byrne, B.W. (2005). Suction caissons for wind turbines. Frontiers in Offshore Geotechnics: ISFOG, London.

Houlsby, G.T. \& Wroth C.P. (1983). Calculation of stresses on shallow penetrometers and footings. Proc. IUTAM/IUGG Seabed Mechanics, Newcastle, 107-112.

Huang, K., Mohanty, B.P. \& Van Genuchten, M.T.h.(1996). A new convergence criterion for the modified Picard iteration method to solve the variably saturated flow equation. Journal of Hydrology 178, 69-91.

Ibsen, L.B. (2008). Implementation of a new foundation concept for offshore wind farms. Int. proc 15th Nordic Geotechnical Meeting, Norway, 19-33.

Ibsen, L.B., Barari, A. \& Kimiaeifar, A. (2010). Analysis of strongly nonlinear oscillation systems using He's max-min method and comparison with homotopy analysis method and energy balance. Sadhana 35, No.4, 1-16. 
Ibsen, L.B., Barari, A. \& Larsen, K.A. (2012). Modified vertical bearing capacity for circular foundations in sand using reduced friction angle. Ocean Engineering 47, 16.

Ibsen, L.B., Liingaard, M. \& Nielsen, S.A. (2005). Bucket foundation, a status. Conference Proceedings Copenhagen Offshore Wind, October, Copenhagen, DK.

Ibsen, L.B., Schakenda, B. \& Nielsen, S.A. (2004). Development of the bucket foundation for offshore wind turbines, a novel principle. Gigawind-Sym. Offshore-Windenergie, Bau- und umwelttechnische Aspekte, Hannover.

ISO. (2000). Petroleum and natural gas industries: Offshore structures: Part 4: Geotechnical and foundation design considerations. ISO19900. Geneva: International Organisation for Standardisation.

Jones, J.E. \& Woodward, C.S. (2001). Newton-Krylov-multigrid solvers for large-scale, highly heterogeneous, variably saturated flow problems. Advances in Water Resources 24, No.7, 763-774.

Ju, S. H. \& Kung, K.J.S. (1997). Mass types, element orders and solution schemes for Richards' equation. Computers and Geosciences 23, No. 2, 175-187.

Kavetski, D., Binning, P. \& Sloan, S.W. (2001). Adaptive time stepping and error control in a mass conservative numerical solution of the mixed form of Richards equation. Advances in Water Resources 24, No.6, 595-605.

Kavetski, D., Binning, P. \& Sloan, S.W. (2002). Non-iterative time stepping schemes with adaptive truncation error control for the solution of Richards' equation. Water Resources Research 38, No. 10, 1211-1220.

Kees, C.E. \& Miller, C.T. (2002). Higher order time integration methods for two-phase flow. Advances in Water Resources 25, No.2, 159-177.

Kimiaeifar, A., Lund, E., Thomsen, O. \& Barari, A. (2011). On approximate analytical solutions of nonlinear vibrations of inextensible beams using parameter-expansion method. International Journal of Nonlinear Sciences and Numerical Simulation 11, No.9, 743-754.

Lai, S.K., Lim, C.W., Wu, B.S., Wang, C., Zeng, Q.C. \& He, X.F. (2009). Newtonharmonic balancing approach for accurate solutions to nonlinear cubic-quintic

Duffing oscillators. Applied Mathematics Modelling 33, No. 2, 852-866. 
Liao, S.J. (2004). On the homotopy analysis method for nonlinear problems. Appl. Mathematics and Computation 47, No. 2, 499-513.

Meyerhof, G.G.(1951). The ultimate bearing capacity of foundations. Geotechnique 2, No.4, 301-332.

Meyerhof, G.G. (1953). The bearing capacity of footings under eccentric and inclined loads. Proc. 3rd Int.Conf. on SMFE, Zurich, 440-445.

Milly, P.C.D. (1985). A mass conservation procedure for time-stepping in models of unsaturated flow. Advances in Water Resources 8, 32-36.

Miller, C.T., Abhishek, C. \& Farthing, M.W. (2005). A spatially and temporally adaptive solution of Richards' equation. Advances in Water Resources 29, No.4, 525-545.

Mirgolbabaei, H., Barari, A., Ibsen, L.B. \& Esfahani, M.G. (2010). Analytical solution of forced-convective boundary-layer flow over a flat plate. Archives of Civil and Mechanical Engineering 10, No. 2, 41-51.

Murff, J.D. (1994). Limit analysis of multi-footing foundation systems. Proc. Of the 8th Int.Conf. on Computer Methods and Advances in Geomechanics, Morgantown, 223244.

Narasimhan, T.N. (2005). Buckingham, 1907: an appreciation. Vadose Zone Journal 4,434-441.

Nayfeh, A.H. (1973). Perturbation Methods. New York: John Wiley \& Sons.

Ngo-Tran. (1996). The analysis of offshore foundations subjected to combined loading. Ph.D. Thesis, University of Oxford.

Okuizumi, N. \& Kimura, K. (2004). Multiple time scale analysis of hysteretic systems subjected to harmonic excitation. Journal of Sound and Vibration 272, No. 3-5,675701.

Omidvar, M., Barari, A., Momeni, M. \& Ganji, D. D. (2010). New class of solutions for water infiltration problems in unsaturated soils. Geomechanics and Geoengineering 5, No. 2, $127-135$.

Ozis, T. \& Yildirim, A. (2007). Determination of periodic solution for a $u 1 / 2$ force by He's modified Lindstedt-Poincare' method. Journal of Sound and Vibration 301, No.1-2, 415.

Philip, J.R. (1974). Fifty years progress in soil physics. Geoderma 12, 265-280. 
Prandtl, L. (1920). Uber die Harte plastischer Korper. Nachr.D.Ges.D.Wiss. Gottingen.

Ramos, J.I. (2009). An artificial parameter-Linstedt-Poincaré method for oscillators with smooth odd nonlinearities. Chaos, Solitons \& Fractals 41, No.1,380-393.

Richards, L. A. (1931). Capillary conduction of liquids through porous mediums. Physics $1,318-333$.

Rolston, D.E. (2007). Historical development of soil-water physics and solute transport in porous media. Water Science and Technology 7, No. 1, 59-66.

Ross, P.J. (2003). Modeling soil water and solute transport - fast, simplified numerical solutions. Agronomy Journal 95, 1352-1361.

Salencon, J. \& Pecker, A. (1995). Ultimate bearing capacity of shallow foundations under inclined and eccentric loads, Part I: Purely cohesive soil. European Journal of Mech.A/Solids 14, No. 3, 349-375.

Sfahani, M. G., Barari, A., Omidvar, M., Ganji, S. S. \& Domairry, G. (2011). Dynamic response of inextensible beams by improved energy balance method. Proceedings of the Institution of Mechanical Engineers, Part K: Journal of Multi-body Dynamics 225, No.1, 1464-4193.

Sfahani, M. G., Ganji, S.S., Barari, A., Mirgolbabae, H. \& Domairry, G. (2010). Analytical solutions to nonlinear conservative oscillator with fifth-order nonlinearity. Journal of Earthquake Engineering and Engineering Vibration 9, No.3, 367-374.

Shield, R.T. (1955). On the plastic flow of metals under conditions of axial symmetry. Proc. Royal Society London, No. 223, 267-287.

Skempton, A. W. (1951). The bearing capacity of clays. Proc. of Building Research Congress, ICE, London, 180-189.

Soliman, A.A. (2006). The modified extended tanh-function method for solving Burgerstype equations. Physica A, 361, 394-404.

Tabuada, M.A., Rego, Z.J.C., Vachaud, G. \& Pereira, L.S. (1995). Two-dimensional irrigation under furrow irrigation: modeling, its validation and applications. Agricultural Water Managemen 27, No. 2, 105-123.

Tan, F.S. (1990). Centrifuge and theoretical modeling of conical footings on sand. Ph.D. Thesis, University of Cambridge. 
Tani, K. \& Craig, W.H. (1995). Bearing capacity of circular foundations on soft clay of strength increasing with depth. Soils and Foundations 35, No.4, 21-35.

Taiebat, H.A. \& Carter, J.P. (2000). Numerical studies of the bearing capacity of the shallow foundations on cohesive soil subjected to combined loading. Geotechnique 50, No.4, 409-418.

Terzaghi, K. (1943). Theoretical soil mechanics. New York, Wiley.

Ukritchon, B., Whittle, A. J. \& Sloan, S. W. (1998). Undrained limit analysis for combined loading of strip footings on clay. J. Geotech. Geoenviron. Engng, ASCE 124, 265-276.

Van Genuchten, M.T. (1980). A closed-form equation for predicting the hydraulic conductivity of unsaturated soils. Journal of the Society of Soil Sciences of America 44, 892-898.

Varado, N., Braud, I., Ross, P.J. \& Haverkamp, R. (2006). Assessment of an efficient numerical solution of the 1D Richards equation on bare soil. Journal of Hydrology 323, No.1-4, 244-257.

Wang, J., Chen, J.K. \& Liao, S. (2008). An explicit solution of the large deformation of a cantilever beam under point load at the free tip. Journal of Computational and Applied Mathematics 212, No.2, 320 - 330.

Watson, P. G.\& Randolph, M. F. (1997). A yield envelope design approach for caisson foundations in calcareous sediments. Proc. BOSS '97, The Hague, 259-273.

Wazwaz, A.M. (2005). Traveling wave solutions for generalized forms of Burgers, Burgers-KDV and Burgers-Huxley equations. Applied Mathematics and Computation 169, 639-656.

Witelski, T.P. (1997). Perturbation analysis for wetting fronts in Richards' equation. Transport in Porous Media 27, No. 2, 121-134.

Witelski, T.P. (2005). Motion of wetting fronts moving into partially pre-wet soil. Advances in Water Resources 28, 1131-1141.

Zhou, X. (1986). Differential transformation and its applications for electrical circuits (in Chinese). Wuhan, China: Huazhong University Press. 